\title{
Shareholder Structure and Discretionary Regulation of Accounting Results in Enterprises: The Case of Cameroon
}

\author{
Kadouamaï Souleymanou, Zakarine Talaka \\ University of Maroua, Maroua, Cameroon
}

\begin{abstract}
Debates on shareholder structure and discretionary management of accounting results have carried forward controversial results. This study is intended to analyze within the Cameroonian context the impact of shareholder structure on the management of accounting results in enterprises. More specifically, its objective is to analyze the impact of shareholder structure on the adjustment of regulating discretionary accounting variables. A panel of enterprises is constituted over the periods 2013, 2014, and 2015 in Cameroon. The modeling of regulating discretionary accounting variables has been carried out according to the model of Jones (1991). The different results obtained show that the degree of concentration of the capital seems not to dissuade the management of result per long-term positions. Foreign ownership and state property stimulate management by regulating discretionary accounting variables.
\end{abstract}

Keywords: shareholder structure, management of results, accounting variables, discretional regulations, control systems

\section{Introduction}

For practically the last 20 years (1997 to 2018), because of cases in the heart of which accounting was involved, accounting results have shown they could be subject to manipulation and did not always reflect accounting practice (Casta, 1997; Boussard, 1997; Grima, 2017; Souleymanou \& Degos, 2018; Elage \& Mard, 2018). Now, data produced by accounting has several impacts on funding, investment, and remuneration mechanisms of equity or managers. This flexibility could lead the designers of financial information to look for (among accounting options at their disposal) elements that enable to give legal information while being advantageous for the objectives set. Elements calculated in accounting result in a discretionary manner are often observed via options (mainly represented by accruals). Several studies try to show that there exist links between shareholder structure and management of accounting results (Mard \& Marsat, 2012; Caby, 2003; Jeanjean, 2001; Charlety, 2001). Meanwhile, elements explaining the reasons of discretionary accounting results for the shareholder structure in the context of embryonic stock market remain unknown.

Still topical today, Lamrani (2012, p.18) relies on Watts and Zimmerman (1986, 1990), to declare that "accounting as an objective representation of an economic reality has found itself in lack of legitimacy" and,

\footnotetext{
Acknowledgment: Souleymanou and Talaka would like to thank the members of the management research team of the Faculty of Economics and Management of the University of Maroua, Cameroon.

Kadouamaï Souleymanou, Associate Professor, Head of Department of Accounting and Finance of the Faculty of Economics and Management of University of Maroua, Maroua, Cameroon.

Zakarine Talaka, Ph.D. student, Department of Accounting and Finance, University of Maroua, Maroua, Cameroon.
} 
"the flexibility of accounting rules allows leaders to exercise their judgement to publish results based on discretionary objectives (p. 24). For this, the accounting result is not an objective of the economic reality, which explained by the growing number of bankruptcy of enterprises and, the multiple scandals that have shaken business community, putting into question the accounting figures published.

Companies considered as high performers based on accounting and financial information suddenly went bankrupt. These bankruptcies fuel the interrogations of researchers in accountancy over the magnitude of discretionary behaviors of managers in the field of accounting and financial information published. Thus, they place accounting and particularly accounting result in lack of legitimacy (Lamrani, 2012). These scandals generate considerable public attention that has discovered some fragility of impartiality and objectivity in accounting results (Lambert \& Sponem, 2003).

Although accounting information is normalized, managers have some flexibility in the field of the choice of accounting options and structuring of transactions. They speak of management of accounting results defined as a deliberate intervention in the process of external financial reporting whose objective is securing personal benefit. Inspired by Schipper (1989, p.92), Cornier and Magnan (1995, p.47), defined the management of result as "the intervention by the management of the firm in the process of financial information with a view to obtain benefit to the detriment of other parties". It can be seen that the search for personal interest is at the basis of management of results.

In a context of agency relation marked by information asymmetry and the opportunism of stakeholders, accounting and financial information published by managers is a signal given to the partners of the enterprise. Accounting result constitutes a pertinent indicator and particularly followed by investors and financial analysts (Mard \& Marsat, 2012).

Managers' discretionary accounting choices can be exercised in the field of evaluation of provisions, of evaluation of production inventory, of the choice of the method of evaluation of production inventory and depreciation. Evaluation can lie on subjective criteria related to the manager's capacity to appreciate risk related to the market. Managers can also act directly on the accounting result, particularly on the cash flow through some decisions-making such as those related to the reduction of R\&D charges, the reduction of discretionary expenditure, the granting of more advantageous loans to customers.

In order to discipline the actors and limit the management of results, corporate governance implements mechanisms of control of managers among which the shareholder structure has been subject to particular interests by researchers. For example, Jeanjean (2001) talks about constraints to the management of results.

Conscious of the finding, the subject of this study is to analyze the explanatory elements of discretionary management of accounting results for shareholder structure. Previous studies have enabled to identify two characteristics of shareholder structure: the concentration and the nature of shareholding. This in the sense that the role of shareholders in the production of accounting and financial information is closely linked to the proportion of the capital that they hold and the nature of those shareholders. As far as discretionary management of accounting results is concerned, two forms are generally studied: the accounting form of results implementing regulating discretionary accounting variables as synthetic form of management and the actual form of management that has a direct effect on the cash flow. The original hypothesis is that as a result of information asymmetry and opportunism, the flexibility granted to executives in accounting matters enables them to act on accounting results. The shareholder structure can therefore exercise effects on the resolution of agency conflict. 
The article is divided into four parts: The conceptual framework is developed in the first part. The empirical literature is reviewed, and research hypotheses are presented in the second part. The methodology is then presented in part three. Finally, the results of the empirical study are generated and are followed by managerial implications and the conclusion of the research.

\section{Justification of the Context Analyzed in Cameroon}

Despite an abundant literature, the results of links between shareholder structure and management of accounting results still remain contrasted and open because of the complexity of theoretical debate, the diversity of the results obtained from theoretical studies, and few studies taking into consideration the specificity of countries (Mard \& Marsat, 2012; Jeanjean, 2001; Cormier \& Magnan, 1998; Ramzi, 2007; Piot \& Janin, 2004). They remain not very studied in contexts without any financial market. For us, Cameroon offers a research field which seems conducive to study. Therefore, we thought it would be pertinent to be interested in companies in Cameroon, and this by virtue of their importance in the economic tissue and many mutations experienced by the sector that is suspected to constitute an ideal seabed for the management of results. The Cameroonian context is appropriate to the study for obvious reasons. Firstly, most of the studies highlighting corporate governance and discretionary management of accounting results have been carried out in contexts with active financial market. Although there exists a stock market (The Douala Stock Market) in Cameroon created since 1st December 2001, we can count only to date three listed companies: Société des Eaux Minérales du Cameroun (SEMC)) listed on 30th April 2006; Société Aricaine Forestière et Agricole du Cameroun (SAFACAM) listed on 9th July 2008; and Société Camerounaise de Palmeraies (SOCAPALM) listed on 7th April 2009. Then, the multiplication of accounting and financial scandals in Cameroonian companies (ADC, CAMAIR, CAMPOST, CAMTEL, CFC, CNIC, CNPS, COFINEST, CRTV, FEICOM, FIFA, PAD, SCDP, SIC, SODECOTON), that highlight shortcomings of governance mechanism prompts us to ask questions on the efficiency of the governance system of the companies in place, and more specifically to ask questions on the efficiency of the shareholder structure to prohibit discretionary accounting practices. Finally, studies have shown that shareholding structure in Cameroon is essentially concentrated (Bimémé, 2016; Wanda, 2001). This situation, a characteristic feature of less active economic markets leads to the timidity of more active and demanding shareholders on the management of key executives. In the light of the above, it becomes important to carry out a study in a context of embryonic financial market as in the specific case of Cameroon. Also, this study would like to be a follow up to the summit of CEMAC Heads of State held on 31st October 2017 in Ndjamena, relative to the transfer of Central Africa Stock Exchange (CASE) to the economic capital (Douala) in Cameroon, stock exchange which until now is located in Libreville (Gabon). Therefore, one can assess the shareholder structure after this transfer only through a study carried out in a context of persistence of governance crisis and very few listed enterprises. We are referring to the waves of restructuring, liquidation, and privatization carried out in some companies of state's portfolio under the combined effects of 1980 economic crisis and structural adjustment on the one hand and to the policies of promotion of investments carried out by public authorities on the other hand.

\section{Conceptual Framework of the Link Analysis Management of Accounting Results and Shareholder Structure}

The conceptual framework enables us to present firstly the management of accounting results, the 
modalities of action, and the constraints to the management of results. Then, on the theoretical level, an analysis of the link between the shareholding structure and the management of the result shall invoke the agency theory, the rooting theory, and the property rights theory.

\section{Presentation of the Management of Accounting Results}

The management of accounting results has been subject to many research studies and constitutes a practice in full emergence. Yet, it remains a concept difficult to define with precision. No consensus is accepted. The most quoted definition is the one of Schipper (1989) for whom the management of accounting results is a deliberate intervention in the process of external financial information in order to appropriate personal gain. Pochet (1998) talks about the manipulation of financial information and constitutes a deliberate intervention in the process of the elaboration of accounting information in order to achieve personal gain. Healy and Wahlen (1999, p.370) consider that the "Earnings management occurs when managers use judgment in financial reporting and in structuring transactions to alter financial reports to either mislead some stakeholders about the underlying economic performance of the company, or to influence contractual outcomes that depend on reported accounting numbers". While, result management is based on the choices of the most suitable rules and accounting policies of valuation for the managerial objectives without the choices being illegal. Everything is based on a legal framework by using the room for maneuver left by accounting rules and accepted accounting principles.

Two elements are essential in the management of results (Marmousez, 2009); firstly, the management of results is only possible when managers have at their disposal a room for maneuver or a discretionary area of operation in the process of preparation of financial statements. Then managers are opportunists and make use of this room for maneuver in order to modify the information communicated to stakeholders. A set of accounting decisions are available to managers merging the possibility of intervention of managers in the process of results management. This intervention can be carried out through the choices of accounting or interpretation of accounting rules on the one hand and through making operating, financing, and investment decision of the enterprise on the other hand. This lays the groundwork for two forms of accounting results management that is the accounting form of management and the actual management form.

Accounting management of results is carried out through the choice of an accounting method, the choice of a portfolio of methods, the study and distribution of results or regulating accounting variables. Regulating accounting variables has been subject to an abundant literature and constitutes a synthetic measure of management and can reflect the strategic management of the result of the dichotomy change of policy/no changes (Cormier \& Magnan, 1995).

The actual management of results according to Rochowdhury (2006) consists of deviant transactions of normal operations of the enterprise, the objective being the achievement of a certain level of result. To that effect, Degeorge, Patel, and Zeckhauser (1999) make a distinction between three performance thresholds: a positive result, the performance level in relation to the accounting period, and the performance level in relation to the projection of analysts. It operates according to a decision taken by the manager that has an impact on the cash flow. The choice of decision-making within the company can focus on operating, financing, and investment decisions (Mard, 2004a; Affes \& Romdhane, 2011). Operating decisions can focus on the abnormal reduction of overheads and administrative charges, the abnormal reduction of R\&D charges, the fact of granting excess rebates etc. Financing decisions are linked to the techniques of financial engineering such as 
deconsolidation and securitization techniques characterized by resorting more and more to financial market to finance the enterprise.

The following remarks have been made to the two forms of management of results, particularly with the reinforcement of corporate governance (Roychohury, 2006; Gunny, 2005). Firstly, the discretionary management of results by accruals constitutes a great risk because it has more chance to draw the attention of auditors than the actual management and on the other hand, the actual management of results is difficult to detect because it is delicate to make a distinction between an optimal management decision and managers' will to manipulate the enterprise's result (Schipper, 1989). The accounting management of results having taken place at the end of the financial year, there exists a great risk for managers to rely only on this form of management to reach a certain threshold of results just in case the reported at the end of the year does not reach that threshold. Graham, Harvey, and Rajgopal (2004) show managers' interest in actual management of results. Also, managers do not have at their disposal all the necessary flexibility in terms of accounting choices. Gunny (2005) also points out that the actual management of results has a negative effect on the future performance of enterprises. Investors are not short-sighted. They sanction these management practices through stock prices, disinvestment etc.

Literature analyzes the management of results according to two main approaches: the opportunist approach of management and the efficient approach (Mard \& Marsat, 2012). The opportunist approach retains the will to deceive stakeholders particularly the readers ${ }^{1}$ of accounting and financial information on the actual economic situation of the enterprise. It retains the functional fixation hypothesis according to which investors are focused on the results published and are not interested in the choices that underlie their elaboration (Aubert, et al 2005); they associate a particular meaning to an object and then become incapable of distinguishing or giving other meanings to that object (Belkaui, 2013).

Incentives to the management of results are multiple. The studies of Watts and Zimmerman (1986) within the framework of positive theory of accounting are considered as fundamental. Three reasons for the management of results are implemented in this theory that is, the reason of incentive measures, the motive of contract of debt, and the hypothesis of political cost. Diversely appreciated in different contexts, the three hypotheses have constituted a basis for an examination of incentives to the management of results. The globalization of the economy having as main argument that the variety of industrial, commercial, and services activities demand requirements in the field of measure is often evoked as incentive to the management of results. Furthermore, a situation of crisis, the development of intangible assets, the taking into consideration of the new border of the firm and taxation (Dumontier, 1996; Raiboud-Turillo \& Teller, 1997) are also evoked as reason of management of results. For Stolowy (2009), several elements can be quoted as factors generating a need for discriminatory management of results: the acuity of competition in a context of crisis, the weight of the environment (deterioration in results and situation), the needs for financing (insufficient equity), the necessity of respecting some indicators (debt to asset ratio, earning per share, balance sheet total, level of turnover in the determination of critical threshold, particularly the appointment of an auditor), the pressure of flattering results from investors and analysts, the desire to ensure a stable course at the launching of private companies wanting to be quoted, and the desire to manage better in tender offer (Kandou \& Cornier, 2016; Teoh, Welch, \& Wong, 1998).

${ }^{1}$ They are users of financial statements and we cannot give their full list: financial analyst, shareholders, investors etc. 
Finally, there are constraints to the management of results. Jeanjean (2001) presents technical constraints, the role of auditors and constraints linked to corporate governance. Technical constraints explain the fact that the development of regulating accounting variables in time obeys to a possibility constraint. In fact, the management of results enables to modify the result during a year but on a given period, the algebraic sum of the result is constant. The auditors play a great role in the field of modulation of behavior of the management of accounting results by managers. Big size auditors for example the big five were, according to Jeanjean (2001) more encouraged to give a quality auditor of a small size. The loss of reputation is more important to big size auditors than to small size auditors. Large audit firms, being richer, are most likely to be prosecuted. Piot and Janin's results $(2004 ; 2007)$ contrast with this observation. They arrive at the fact that Anglo-Saxon big size auditors seem not to show a more significant accounting prudence than the other law firms in the French environment. As far as corporate governance is concerned, shareholder structure and the concentration or nature of shareholders can influence the management of accounting results by managers. Shareholding in itself represents all the shareholders. Shareholding is concentrated when a shareholder or a group of shareholders holds a bloc of shares of the enterprise in opposition to diffused ownership. This situation implements the concentrated control.

\section{Theoretical Explanations of the Management of Accounting Results and Shareholder Structure}

The influence of shareholder structure on the management of accounting results can be analyzed under a triple theoretical prism: the agency, the rooting, and property rights.

The agency theory, stemming from the studies of Berle and Means (1932) implements the development of joint state enterprises requiring some management competence, has highlighted the agency relation. This relation appears once an individual (or an enterprise) trusts partially the management of its own interests to others on the basis of detention, unavoidable by the principal, of some know-how or some information (Raimbourg, 1997). The cognitive incapacity to write a comprehensive contract and the active behavior of actors for the search of personal benefits (Coriat \& Weintein, 1995), favor in the agent an opportunist behavior in the context marked by information asymmetry that could lead to a conflict between the principal and the agent called agency conflict. Contracts being incomplete, the execution of the transaction shall be done without any cost. The theory of property right advocates to overcome this problem by granting property rights to the assets whose ultimate goal according to Bell and Meiselman (1995) is to highlight how this or that type of property influences on this or that agent and therefore how this or that system of private law acts on this or that economic system, on its efficiency and on its functioning (Amann, 1999). Therefore, the primary function of property right is to give individuals incentives to create, to conserve and valorize the assets (Coriat \& Weinstein, 1995, p. 81; Amann, 1999). The fundamental hypothesis of the theory of property right is that the allocation to individuals of property right perfectly defined is the condition of economic efficiency (Coriat \& Weinstein, 1995, p. 88).

Corporate governance therefore appears as a rampart whose challenge is to give confidence and enable partners (investors, proprietors, etc.) to have means in order to exercise a real control on the management of their asset (Alexandre \& Paquerot, 2000). The shareholder structure as mechanism (Mard \& Marsat, 2012) of governance is implemented in literature therefore its influence on the management of results can be understood under two angles: under the angle of concentration of shareholders and under the angle of the nature of different shareholders. 
The concentration of shareholders among a small number of shareholders enables a better control of managers and conversely, diffuse shareholding companies suffer from a control deficit, likely to encourage the management of results (Mard \& Marsat, 2012). The pressure of financial markets would therefore be less within the framework of concentrated shareholding companies. The concentration of shareholders among a small number of shareholders therefore makes the interests coincide with minor shareholders.

Meanwhile, the concentration of shareholders can constitute a source of conflict between minor and major shareholder, generally termed agency conflict of type II. This can generally be observed when the major shareholder is at the same time the manager of the company and can as such own private profits because he holds most shares on the one hand and his strategic position within the company on the other hand. The management of results can therefore serve as the rooting of managers in accordance with the rooting theory (Mard \& Marsat, 2012).

The nature of the shareholder can also influence the management of results. This influence depends on the objective set and the investors' investment horizon. Many types of shareholders are therefore implemented in literature: family shareholding, foreign shareholding, national shareholding, and state shareholding.

Family shareholding is associated with a least management of results for three reasons (Mard \& Marsat, 2012): Firstly, it is supposed because of a heritage implication often very strong, to operate a more effective control on the firm and its managers; secondly, the family shareholder in general gives a greater place to long term objective; thirdly, in case of revelation of accounting irregularities, the family shareholding has a lot to lose in terms of family reputation. In a different way, the concentration of shareholding in the hands of the family can be a means of owning private profit to the detriment of minor shareholders. The absence of strong governance mechanism and the asymmetry of information are thus favorable conditions for the management of results.

They speak of state shareholding when the State partially or totally holds the capital of an enterprise. This is generally observed in the case of public companies or parastatals depending on whether the State is the exclusive or partial owner of the capital of the enterprise. It is their shareholder; it regulates their activity. It gives or makes accounting standards compulsory, sanctions frauds and scams in accounts, sanctions illegalities. Meanwhile, the role of the State as shareholder is to qualify. These enterprises evolve in a context of competition and in an open environment. Because the State's objective is public service and general interest, these enterprises are intended to render public service to State's citizens. The position of the State is therefore ambiguous, and the strategies of the said enterprises depend more on the group to which they belong than on their shareholding. If their traditional objective is to guarantee the mission of public service, the search for profitability has more and more become a priority. Public enterprises are confronted with a lack of capitals and the challenge of development on international financial markets. These challenges catalyze change and thus, the State shareholder must promote good governance within these enterprises, and develop a dialogue with the management of the enterprise. In reaction to economic difficulties attributed to management errors of the enterprises and whose remedy appears to be undeniably the reinforcement of the control, the State must promote good management and accountability of enterprises. The State must behave as an informed and active shareholder and define a clear and coherent shareholder strategy so as to guarantee that the government of public enterprises is exercised in a transparent and responsible manner, with all the professionalism and necessary efficiency. The development for prosecution for abuse of social assets has reached state's enterprises 
and shows well the activism that State's shareholding in the field of promotion of governance has taken. Therefore, public shareholding enables some groups of enterprises to develop.

Foreign shareholding refers to the holding of part or all the capital of the enterprise by moral or physical person who do not stay or do not have their headquarters in the national territory. The international shareholding enterprise or foreign-invested enterprise must be considered as the one whose part or all the capital is held by one or many foreign shareholders (Djoutsa, Ndjanyou, \& Nga Nkouma, 2017). This type of shareholding has developed very quickly these last years with changes that occurred on the markets and the globalization of the economy that more and more pushes foreigners (physical or moral person) in search of better investments to expatriate economically. Here, we note deregulation, decompartmentalization, and international integration. With privatizations which started since 1980s, we observe a strong participation of foreigners in the capital of enterprises which exclusively fall under the State or at least nationals.

\section{Corporate Governance, Shareholder Concentration, and Management of Accounting Results: Review of Empirical Literature and Research Hypothesis}

Corporate governance has sometimes been presented as the bulwark to scandals they suspect the manner it is chosen, implemented, and controlled by the managing team. The concept is not new, but its magnitude has expanded these last years with the publication of many reports and guides for good conduct over the world. According to Beffa (2001), it developed in the 1980s in the economic literature before appearing in the 1990s in the diary of political agenda and newspapers articles. According to Djongoue (2007), it is situated in the increasingly pressing requirement of reliable and credible accounting information, essential variable in investors' behavior and, of the necessity of reducing conflicts of interests and the problem of information within enterprises. Then, the question is focused on firm's internal mechanisms through which shareholders (mandators) seek to maximize control on managers (mandated) (Vishny \& Shleiffer, 1997). In a broad sense, the acceptation of governance refers to the notion of control whose main question is discipline. In other words, it refers to the modalities of organization and exercise of power when a collective action is at stake (Degos \& Souleymanou, 2016), the objective being to avoid conflicts of interests or at least looking for an impartial solution.

In fact, they distinguish between two main models of corporate governance in literature: the shareholder ${ }^{2}$ model and the stakeholder ${ }^{3}$ model.

The first model is characterized by a strong atomization of shareholding and a mechanism of external control by the market of corporate control and managers' market (Plihon, Posard, \& Zarlowski, 2001). Its origin is found in the simplified representation of the firm: Shareholders are the sole proprietors of the firm (Charreaux \& Desbrieres, 1998). The postulate that characterizes the Anglo-Saxon model is that the interests of all those who participate in the development of the enterprise apart from shareholders, are taken into consideration, through contracts concluded with them and that only the interests of shareholders, residual creditors, do not benefit from any contractual protection and must be protected by the implementation of a system of governance (Hyafil, 1997). It's the model of shareholder sovereignty (Degos \& Souleymanou, 2016). The second model is characterized by the existence of reference major shareholders and control block holders.

\footnotetext{
2 The model shareholder is the model of corporate governance developed by Anglo-saxon countries.

3 The model stakeholder is the model of corporate governance developed in continental Europe where financial market is less developed and where there exits reference big shareholders holders of control blocks.
} 
These shareholders make the control and the supervision of managers' easy (Charletty, 2001). The small shareholders seem not to be interested in the life of the enterprise ${ }^{4}$. The cost of an active participation exceeds the expected benefits which are proportional to the participation in companies' capital. Financial markets play a secondary role; the financial and human resources allocation result from an internal management. This model is found in countries of French legal tradition where good accounting standards, a good protection of investors, and a good implementation of laws are negatively correlated with shareholding concentration (Caby, 2003).

\section{Shareholding Concentration and Management of Accounting Results}

Literature presents many studies testing the relation between the shareholding concentration and the management of accounting results. Some authors admit that shareholding concentration deter the adjustment of regulating discretionary accounting variables by managers. The accounting behavior of diffuse shareholding companies is supposed to be more active than the enterprises controlled (Jeanjean, 2000; Dempsey, Hunt, \& Schroeder, 1993). Smith (1976) therefore thinks that the existence of blocks of shareholders enables to limit the smoothing of results by managers. He will be followed later by Dempsey et al. (1993) and Jeanjean (2000) for whom the nonexistence of dominant shareholder leads to the ranking of profit items among the elements of exploitation and losses in exceptional results. The basic argument of shareholding concentration is that shareholders holding a block of shares can influence the votes during general assembly's; the important number of voices in their possession makes them to avoid mobilizing other shareholders in order to vote some resolutions or contest the management of managers. They play the role of leaders during assemblies (Alexandre \& Paquerot, 2002). As far as small shareholders are concerned, despite their efforts to associate, their lack of cohesion quite often removes from them the possibility to weight efficiently and the enterprises that account for their results and projects in a transparent and legible manner are rare (Daniel, 2001).

In the reverse, Piot and Janin (2004; 2007) and Ramzi (2007) find that the shareholding concentration seems not to deter resorting to regulating accounting variables to modulate the result.

Mard and Marsat (2012) find in their study that shareholding concentration limits the management of result up to a certain threshold and this relation changes when the main shareholder holds more than half of the shares.

Therefore, it appears that the relation between shareholding concentration and the results remains contrasted. Many parameters related to the methodology adapted, to the context of studies and to the measure of shareholding are likely to influence this relation. However, the theory teaches us that the existence of block of shareholders supposes a better control of managers. This leads us to put forward the following hypothesis, H1: There exists a deterrent effect of shareholding concentration on the management of accounting results.

\section{Nature of Shareholding and Management of Accounting Results}

Several types of shareholders are highlighted in the studies on the relation between the structure of shareholding and the management of results. In our study, we retain state shareholding and foreign shareholding.

\section{State Shareholding and Management of Accounting Results}

They talk about state shareholding when the State holds partially or totally the capital of the enterprise. For Amann (1999), in companies with public participation, discretionary practices will tend to be more important.

\footnotetext{
${ }^{4}$ In France, less than $10 \%$ of them take part in general assemblies and more than half do not vote (Charlety, 2001).
} 
Managers are quite often motivated by their own interest because they bear the costs or the profits of their choice. Ben-Nasr et al. (2009) quoted by Mard and Marsat (2012) find from an international sample of privatized firms that state shareholding is associated with the least quality of higher discretionary accounting variables or accruals.

In the enterprises where the State holds the capital partially or totally, Begne (2012) notes transgressive practices negatively perceived by all the managers. Their objective is to be maintained in their post the longest time possible. All the managers have kept a privileged and controlled access to information, the presentation of dressed balance sheet whose objective is to minimize the results published (Begne, 2012). The rooting effect is stronger among public enterprises.

In accordance with the politico-contractual theory, the enterprises where the State is a shareholder are submitted to more political costs particularly in the regulatory domain. In order to minimize the costs, they can lend themselves to a management of results according to the following hypothesis, H2: The State shareholding negatively influences the management of accounting results.

\section{Foreign Shareholding and Management of Accounting Results}

Since the beginning of 1980s, many enterprises came out of State's portfolio to be in the private domain. That led to an internationalization of the shareholding of enterprises (Djoutsa et al., 2017). Foreign investors are worried by the improvement of their shareholder value. Within this framework, they are going to play an important role in terms of controlling managers and demanding greater transparency in the results of enterprises. According to Bughin, Finet, and Monaco (2011), they have at their disposal reduced access and information processing costs that enable them to avoid enterprises with a high level of information asymmetry. This provision therefore permits foreign investors to be able to criticize and question management decisions and accounting choices made by managers.

In quoting Fontagne and Toubal (2010, p. 29), Djoutsa et al. (2017) think that the motivation of an investor to embark on an international adventure is far from being:

(a) The exploitation of his industrial know-how on foreign markets, because an investor can prefer to produce in his country and then export his products abroad.

(b) Cost minimization: Using a subcontractor in a country where labor is cheap could be an excellent option as it is observed in the industry of sport stuff and clothing.

(c) Presence on the spot: In the domain of services, the necessity of a presence on the spot is needed; it is also possible to imagine franchising local partners in many cases.

The motivation of foreign shareholders is pending on profitability greater than the one that they would obtain in investing at the national level. The role of accounting is therefore to satisfy the different needs needed when the environment evolves (Degos \& Souleymanou, 2016) particularly shareholder environment. Djoutsa et al. (2017) find that the presence of foreign shareholders in the enterprise's capital has a positive influence on the performance of the latter. Their pressure on the management of the enterprise enables to create value. Furthermore, they obtain that the more important that participation is, the more performing the enterprise is. Literature has retained that the level of participation in the capital confers some power on the manager. In accordance with the agency theory, the important shareholders in terms of participation will be more active in terms of controlling managers. In order to verify in the Cameroonian context, we put forward the following hypothesis, H3: Foreign shareholding negatively influences management results. 


\section{Methodology}

Our methodology is divided into four stages: the presentation of the sample and data, the measure of explanatory and explained variables and descriptive statistics.

\section{Selection of Sample and Data}

The study is about industrial enterprises. The constitution of the sample has been done by the method of reasoning choice; this compared to the literature. Enterprises must fulfill a number of criteria. We are working on a secondary data. We have used the file of the National Institute of Statistics to determine our sample. This institution centralizes statistical data of enterprises per branch of activities. It was then easy for us to extract the enterprises subject of our study. The data obtained concerns the periods 2013-2015. Recent data (2016-2018) was not yet available. Over a total population of 140 enterprises from this file, we have selected 39 enterprises in this study. The following table describes the selection process.

Table 1

Criteria of Selection of the Sample

\begin{tabular}{ll}
\hline Criteria of selection & Number \\
\hline Industrial companies obtained from the file of NIS over the period 2013-2015 & 140 \\
Minus listed companies & 3 \\
Minus enterprises with no data over two successive years & 31 \\
Minus companies not related to a well-defined activity & 67 \\
Final sample & 39 \\
\hline
\end{tabular}

In order to give a longitudinal dimension to our study and avoid the limits relative to cross-sectional studies, we are working on panel data ${ }^{5}$. We have constituted a non-cylinder panel ${ }^{6}$. Given the availability, accessibility, and confidentiality constraints that surround data on the structure of shareholding and the management of accounting results, we have taken our attention to the secondary data from the NIS file over the years 2013, 2014, and 2015.

\section{Measure of Explanatory and Explained Variables}

Explained variable. The explained variable is the management of accounting results. We select the accounting form of management of results which has several methodologies in literature: the study of a particular accounting method, the study of a portfolio of methods, the study of the distribution of methods and regulating accounting variables. Regulating accounting variables have been selected in this study. The possibilities of management of result can be situated at the level long term posts and at the level of short-term posts as well. In order to understand the different opportunities offered to preparers of financial statements and to give more rigor to our study, we use the two possibilities of management of regulating accounting variables that are total regulating accounting variables and short-term exploitation regulating accounting variables. The calculation models are as follows:

$$
\operatorname{VCRT}_{i t}=\left(\operatorname{Var} \mathrm{AC}_{\mathrm{it}}-\operatorname{Var}_{\mathrm{ENCAISS}}\right)-\left(\operatorname{Var} \mathrm{PC}_{\mathrm{it}}-\operatorname{Var}_{\mathrm{it}} \mathrm{DLT}_{\mathrm{it}}\right)-\mathrm{DAP}_{\text {it }}
$$

\footnotetext{
${ }^{5}$ We owe panel data three main advantages: They enable to identify the effects which are not in cross section, they enable to control the presence of unobservable heterogeneity, they enable to formulate dynamic models. Cross sections are only single shots of a dynamic phenomenon whereas panel data are repeated shots and therefore they enable to catch a movement even if the time step between two shots can give the impression of clashing movements (Magnac, 2001).

${ }^{6}$ A panel is non-cylindrical when the number of points in the temporal dimension is not the same for the enterprises contrary to a cylindrical panel which has the same number of points in the temporal dimension for all the enterprises.
} 


$$
\text { VCRTexp } p_{i t}=\left(\operatorname{Var}_{\mathrm{AC}_{\mathrm{it}}}-\operatorname{Var}_{\text {ENCAISS }}\right)-\left(\operatorname{Var}_{\mathrm{PC}} \mathrm{PC}_{\mathrm{it}}-\operatorname{Var}_{\mathrm{DLT}} \mathrm{it}_{\mathrm{it}}\right)
$$

$\mathrm{i}=$ the company 1 à 50; t: the year: 2012, 2013, and 2014; Var AC: variation of circulating asset; Var ENCAISS: variation of cash and assimilated accounts; Var PC: variation of circulating asset; Var DLT: variation of long term debt passed to circulating asset; DAP: depreciation charges and provision; VCRT: total regulating accounting variable; VCRTexp: exploitation (or short term) total regulating accounting variables.

The propensity of firms to manage their accounting results is quite often measured by estimating discretionary accounting "regulations". Under the hypothesis of management of results, it appears that there exist a normal part of regulating accounting variable and an abnormal part (or discretionary). The normal part results from the normal and sincere implementation of accounting principles and rules. Several models have been proposed in the literature in order to make a distinction between these two parts. Jeanjean (2003) and Chaouki (2008) have examined these models in their studies: Healy's model (1985), De Angelo's model (1986), Jones' model (1991), Kang and Sirvaramakrishnan's model (1995), and Chalayer and Dumontier's model (1996). Most of the studies on the management of results adopt the model of Jones (1991) or the modified version of that model.

In conformity with the different models above mentioned and given that the realities and constraints linked to the availability and completeness of data, we opted for Jones' model (1991). This model remains well used in literature. Moreover, it is based on the assumption of homogeneity among the companies of the same sector of activities. Our study comes up to that requirement. It is presented as follows:

$$
\begin{gathered}
\operatorname{VCRT}_{\text {it }}=\beta_{0}+\beta_{1} \operatorname{VarCA}_{\text {it }} / \mathrm{TA}_{\mathrm{it}-1}+\beta_{2} \mathrm{IMMOB}_{i t}+\varepsilon_{\mathrm{it}} \\
\mathrm{VCRTexp}_{\mathrm{it}}=\alpha_{0}+\alpha_{1} \operatorname{VarCA}_{\mathrm{it}} / \mathrm{TA}_{\mathrm{it}-1}+\varepsilon_{\mathrm{it}}
\end{gathered}
$$

i: the company; $t$ : the year; Var CA: the variation of turnover; IMMOB: gross tangible assets. The variables VCRT and VCRTexp are defined in the models (1) and (2). The discretionary regulating accounting variables are represented by the disturbance $\left(\varepsilon_{\mathrm{it}}\right)$. Variables are standardized by the total asset of the year ( $\left.\mathrm{t}-1\right)$ in order to avoid heterocedasticity problem.

The difference between total regulating accounting variables (VCRT) and regulating accounting variables considered as normal (VCRN) gives discretionary regulating accounting variables (VCRD):

$$
\begin{gathered}
\mathrm{VCRT}_{\mathrm{it}} / \mathrm{TA}_{\mathrm{it}-1}=\mathrm{VCRN}_{\mathrm{it}} / \mathrm{TA}_{\mathrm{it}-1}+\mathrm{VCRD}_{\mathrm{it}} / \mathrm{TA}_{\mathrm{it}-1} \text { alors: } \mathrm{VCRD}_{\mathrm{it}} / \mathrm{TA}_{\mathrm{it}-1}=\mathrm{VCRT}_{\mathrm{it}} / \mathrm{TA}_{\mathrm{it}-1}-\mathrm{VCRN}_{\mathrm{it}} / \mathrm{TA}_{\mathrm{it}-1} \\
\mathrm{VCRDT}_{\mathrm{it}} / \mathrm{TA}_{\mathrm{it}-1}=\mathrm{VCRT}_{\mathrm{it}} / \mathrm{TA}_{\mathrm{it}-1}-\left(\beta_{0} / \mathrm{TA}_{\mathrm{it}-1}+\beta_{1} \operatorname{VarCA}_{\mathrm{it}} / \mathrm{TA}_{\mathrm{it}-1}+\beta_{2} \mathrm{IMMOB}_{\mathrm{it}} / \mathrm{TA}_{\mathrm{it}-1}\right) \\
\mathrm{VCRDexp}_{\mathrm{it}} / \mathrm{TA}_{\mathrm{it}-1}=\mathrm{VCRTexp}_{\mathrm{it}} / \mathrm{TA}_{\mathrm{it}-1}-\left(\alpha_{0} / \mathrm{TA}_{\mathrm{it}-1}+\alpha_{1} \operatorname{VarCA}_{\mathrm{it}} / \mathrm{TA}_{\mathrm{it}-1}\right)
\end{gathered}
$$

VCRN: normal regulating accounting variables; VCRDT: total discretionary regulating accounting variables; VCRDexp: exploitation discretionary regulating accounting variables. The other variables are defined above. The estimators of parameters " $\beta$ " and " $\alpha$ " are estimated for each year.

These processes can be summarized in three steps that will be followed in order to determine discretionary regulating accounting variables:

Step 1: Calculation of total discretionary regulating accounting variables.

Step 2: Cross-sectional estimation of parameters of regression of models 3 and 4 that enable to calculate the parameters of accounting variables of normal regulation.

Step 3: Determination of accounting variables of discretionary regulations.

Explanatory variables. We have retained as explanatory variables the concentration of shareholders, state shareholding, and foreign shareholding. In order to be coherent with literature, we borrow from Djelassi (1996) and Charreaux (1991) quoted in our context by Wanda (2001), the measure of concentration of shareholders as 
presented in the following table. State shareholding is measured by the proportion of shares held by the State or public collectivity and foreign shareholding is measured by the proportion of shares held private foreigners, moral or physical people.

State property is synonymous with state shareholding and foreign property is synonymous with foreign shareholding. We have retained in this framework only the participation of foreign private shareholders. The interest on the proportion of the capital as measure of the different properties lies in the fact that the dichototomous variable $(0 / 1)^{7}$ is not enough to know the flexibility of a company to manipulate its results. It does not permit to understand the intensity of the impact of the choice of a particular accounting technique (Jeanjean, 1999) since it does not distinguish any capital increase held by this or that shareholder of $10 \%$ of progression by $20 \%$ for example.

We have introduced two control variables from the positive theory of accounting and this for the requirements of the model but also because the concentrations of the capital and shareholding do not constitute the only variables likely to influence the behavior of managers in the field of the management of results. The variables "Size of the debt" come from the positive theory of accounting.

Table 2

Measure of Variables

\begin{tabular}{|c|c|c|}
\hline Variables & Nature & Measure \\
\hline Cocen & Quantitative & $\begin{array}{l}\text { CONCEN } 1=\mathrm{C} \text { si } \mathrm{C}<20 \% \text { low concentration } \\
=20 \% \text { si } \mathrm{C}=20 \% \\
\text { CONCEN } 2=0 \text { si } \mathrm{C}<20 \% \text { average concentration } \\
=\mathrm{C}-20 \% \text { si } \mathrm{C}<50 \% \\
=30 \% \text { si } \mathrm{C}=50 \% \\
\text { CONCEN } 3=0 \text { si C }<50 \% \text { strong concentration } \\
=\mathrm{C}-50 \% \text { si } \mathrm{C}=50 \%\end{array}$ \\
\hline $\begin{array}{l}\text { State } \\
\text { Foreigners }\end{array}$ & Quantitative & $\begin{array}{l}\text { Proportion of capital held by the State } \\
\text { Proportion of capital held by foreigners }\end{array}$ \\
\hline Debts & Quantitative & DEBTS $=$ Financial debts/total assets \\
\hline Size & Quantitative & SIZE $=$ Logarithm of total assets \\
\hline
\end{tabular}

The software STATA is the one used for data processing. Given that our study is on the regressions on panel data, STATA is the software par excellence for such processing. Thus, for the robustness test of relations between explanatory variables and explained variables, we use the Pearson correlation coefficient and the R square adjusted coefficient of determination. For the global significance test of our models of analysis, we use Fischer's statistics; and the student $t$ statistics shall be used for the individual significance test of variables. We have carried out a stack ${ }^{8}$ per individual with Excel software before proceeding to the statistical processing with the software STATA15.1

\section{Descriptive Statistics on Variables}

We are going to present the descriptive statistics on the families of regulating accounting variables and we shall analyze the variable concentration of capital. The table below summarizes the descriptive statistics relative to VCRT and VCRTexp.

\footnotetext{
7 This dichotomous variable is more appropriate for the study of the type of shareholder.

${ }^{8}$ There exist two types of stacking data: stacking by individual where the $\mathrm{T}$ achievements of each individual are stocked in a column vector and the $\mathrm{N}$ column vectors thus obtained are then stacked in a column vector and the $\mathrm{T}$ column vectors thus obtained for all the dates are then stacked one after the other.
} 
Table 3

Description of VCR Over Three Years

\begin{tabular}{lllll}
\hline & Minimum & Maximum & Mean & Standard deviation \\
\hline VCRTD & -1.3940447 & 4.3664701 & -0.002599600 & 0.5047399617 \\
VCRDexp & -1.3951618 & 4.4656693 & 0.018809824 & 0.5123679012 \\
VCRT & -1.5061280 & 4.5511046 & 0.017189998 & 0.523609823 \\
VCRTexp & -1.4927204 & 4.5929524 & 0.046198337 & 0.522212206 \\
\hline
\end{tabular}

Only the variable VCRTD presents a negative mean. All the others are positive and are strognly scaterred as shown by the standard deviations. These means express a tendency to a bullish management of results over the period of study. The following table informs us on the descriptive statistics of explanatory variables and control variables.

Table 4

Description of Explanatory Variables

\begin{tabular}{lllll}
\hline & Minimum & Maximum & Mean & Standard deviation \\
\hline Size & 8.397998 & 12.093344 & 10.240712 & 0.75563234 \\
Debt & 0.00000 & 0.82674112 & 0.08160170 & 0.12320592 \\
PubCAM & 0.0000000 & 1.000000 & 0.1098252 & 0.2569100 \\
Foreigners & 0.0000000 & 1.000000 & 0.4407810 & 0.41949762 \\
CONCEN2 & 0.2800000 & 0.3000000 & 0.2998198 & 0.00189831 \\
CONCEN3 & -0.5000000 & 0.500000 & 0.33954234 & 0.21700167 \\
\hline
\end{tabular}

We note a strong shareholding concentration of the enterprises of the sample. It is $33.9 \%$ on average. We can say that on average, the main shareholding holds $83.9 \%$ of the capital of the enterprises of the sample ${ }^{9}$. This result matches Wanda's studies (2001) in the same context. In a second case of average concentration, it appears that the main shareholding holds on average $59.98 \%$ of the capital of the enterprises of the sample ${ }^{10}$. The foreign shareholding holds on average $44 \%$ of the capital of the sample against a participation of $10.9 \%$ of the State. Therefore, this expresses that Cameroonian economic tissue is much more characterized by a strong participation of foreign investors. Debt on average represents $8 \%$ of total asset. It is $82.67 \%$ of the total asset in the most indebted enterprises. As far as the size is concerned, it is on average $10.24 \%$ and varies between $8.39 \%$ and $12.09 \%$. The enterprises of the sample are strongly scattered according to their size.

Table 5

Description of Variables of the Balance Sheet and Income Statement (Over Three Years)

\begin{tabular}{llllll}
\hline & Mean & Médian & Standard deviation & Min & Max \\
\hline IMMOB & $39,247,663,354$ & $9,671,238,389$ & $64,074,492,175$ & $298,489,239$ & $3.0795 \mathrm{E}+11$ \\
Cr & $6,364,153,118$ & $1,983,897,015$ & $14,542,429,887$ & $8,641,174$ & $94,850,000,000$ \\
AC & $19,341,754,445$ & $7,899,013,952$ & $34,959,472,399$ & $85,138,770$ & $2.095 \mathrm{E}+11$ \\
ENCAISS & $4,972,757,521$ & $433,954,256$ & $16,799,434,406$ & 637,210 & $1.09 \mathrm{E}+11$ \\
CA & $48,735,383,771$ & $10,616,486,288$ & $1.03447 \mathrm{E}+11$ & $7,200,000$ & $6.55606 \mathrm{E}+11$ \\
TA & $69,302,435,160$ & $21,845,066,224$ & $1.20556 \mathrm{E}+11$ & $67,781,904$ & $9,340,000,000$ \\
PC & $14,701,683,560$ & $5,154,065,937$ & $26,624,166,460$ & $33,637,834$ & $1.5183 \mathrm{E}+11$ \\
DAP & $2,267,474,888$ & $689,560,603$ & $3,860,227,643$ & $8,677,812$ & $17,436,000,000$ \\
DBTS & $6,482,176,482$ & $1,315,299,628$ & $13,049,045,634$ & 0 & $64,625,000,000$ \\
RN & $2,903,032,310$ & $107,377,929$ & $8,783,560,086$ & $-8,956,557,439$ & $52,002,000,000$ \\
\hline
\end{tabular}

\footnotetext{
9 The sum of $83.9 \%$ is obtained by adding $20 \%$ (low concentration) and $30 \%$ (average concentration) and $33.9 \%$.

10 The value of $59.98 \%$ is obtained by adding the sum of $20 \%$ (low concentration) and $29.9 \%$ (average concentration).
} 
The descriptive statistics of asset and liabilities variables of the balance sheet and income statement variables are represented in the table above. The average total assets amount to $69,302,435,160$ made of about $56.63 \%$ of property, plant, and equipment and of $9.18 \%$ of receivables and assimilated accounts. The enterprises' debts of the sample are concentrated around the mean $6,364,153,118$, about $28 \%$ of current assets. And a mean of $7.18 \%$ of receipts marked by a strong concentration around 4,972,757,521, average receipt.

The circulating liability (PC) amounts on average to $14,701,683,560$ and varies between $1.5183^{\mathrm{E}}+11$ and $33,637,834$, the depreciation charges (DAP) in the order of 2,267,474,888 and long-term debts passed to circulating liabilities (DETTES) on average 6,482,176,482. These statistics illustrate a strong use of property, plant, and equipment (that is $57 \%$ of total assets) to manage accounting results.

Table 6

Pearson's Correlation Ratio Among Explanatory Variables

\begin{tabular}{|c|c|c|c|c|c|c|}
\hline & TAILLE & DETTE & PubCAM & ETRANG & CONCEN2 & CONCEN3 \\
\hline TAILLE & 1.0000 & & & & & \\
\hline DETTE & $\begin{array}{r}-\odot .0827 \\
\odot .3755\end{array}$ & 1.0000 & & & & \\
\hline PubCAM & $\begin{array}{l}\odot .3791^{*} \\
\odot . \odot \odot \odot \odot\end{array}$ & $\begin{array}{r}-0.1398 \\
0.1326\end{array}$ & 1.0000 & & & \\
\hline ETRANG & $\begin{array}{l}\odot .0201 \\
\odot .8297\end{array}$ & $\begin{array}{l}\odot .1153 \\
\odot .2157\end{array}$ & $\begin{array}{c}-\odot .3071^{*} \\
\odot .0 \odot \odot 8\end{array}$ & 1.0000 & & \\
\hline CONCEN2 & $\begin{array}{r}-0.1488 \\
0.1093\end{array}$ & $\begin{array}{l}\odot .0185 \\
\odot .8431\end{array}$ & $\begin{array}{r}-0.1345 \\
0.1482\end{array}$ & $\begin{array}{r}-0.0080 \\
0.9322\end{array}$ & $1.00 \odot \odot$ & \\
\hline CONCEN3 & $\begin{array}{l}\odot .0366 \\
\odot .695 \odot\end{array}$ & $\begin{array}{c}-0.2363^{*} \\
0.0103\end{array}$ & $\begin{array}{r}-0.0321 \\
0.7310\end{array}$ & $\begin{array}{l}\odot .0994 \\
\odot .2863\end{array}$ & $\begin{array}{l}\odot .1513 \\
\odot .1034\end{array}$ & $1.000 \odot$ \\
\hline
\end{tabular}

Note. * Significant to $5 \%$.

Pearson's correlation shows an independence of explanatory variables over the period of studies. Because, despite the existence of significant correlation between the size and public shareholding, between foreign shareholding and public shareholding, and between the debt and the strong concentration, these coefficients of correlation are not high (the highest is 0.3791 ) to cause a problem of multicolinearity.

Having therefore established the independence of explanatory variables and removed doubt on the problem of colinearity, we continue with the specification of the empirical model for regressions.

\section{Specification of the Empirical Model of Analysis}

Any study on the panel data faces the problem of specification of the model of analysis. The first thing that should be verified is the nature (homogeneous or heterogeneous) of the generating process of data. This enables to know if one is entitled to assume that the theoretical model studied is identical with all the individuals or on the contrary there exist specificities proper to each enterprise. Where appropriate, the source of heterogeneity must be identified.

In order to discriminate between the common effects and individual effects, we have estimated the 
common effects model within the framework of a homogeneous sample and the fixed effects model within the individual effects model. The common effects model is estimated by the ordinary least square method and the fixed effects model is estimated by the estimator within also called Least Square Dummy Variable (LSDV). We put forward the following fixed effects model:

$$
\begin{aligned}
& \text { VCRDT }_{\text {it }}=\alpha_{i}+\alpha_{1} \text { CONCEN }_{i t}+\alpha_{2} \text { CONCEN }_{i t}+\alpha_{3} \text { ETRANG }_{i t}+ \\
& \alpha_{4} \text { PubCAM }_{i t}+\alpha_{5} \text { DETTE }_{t-1 \text { it }}+\alpha_{6} \text { TAILLE }_{\text {it }}++\varepsilon_{\text {it }}
\end{aligned}
$$

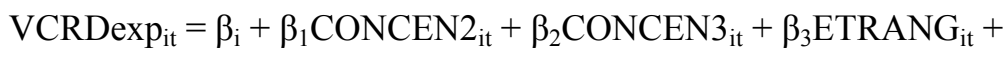

$$
\begin{aligned}
& \beta_{4} \text { PubCAM }_{\text {it }}+\beta_{5} \text { DETTE }_{\text {t- lit }}+\beta_{6} \text { TAILLE }_{\text {it }}++\varepsilon_{\text {it }}
\end{aligned}
$$

An essential question is to know if the effects specific to enterprises $\left(\alpha_{\mathrm{i}}\right)$ are identical (Common effects) or significantly different (fixed individual effects). A Fisher test is constructed in the following manner: under the null hypothesis of homogeneity of enterprises (Ho: $\alpha_{1}=\alpha_{2}=\ldots \alpha_{36} ; \beta_{1}=\beta_{2}=\ldots=\beta_{36}$ ), the estimated model corresponds to the common effects model whereas under the alternative hypothesis ( $\mathrm{H} 1: \alpha_{1} \# \alpha_{2} \# \ldots \# \alpha_{36} ; \beta_{1} \# \beta_{2}$ $\left.\# \ldots \# \beta_{36}\right)$, the estimated model is the individual effects model.

The implementation of Fisher's test follows directly during this estimation of the fixed effects model with STATA. The constraints $\alpha_{i}$ and $\beta_{i}$ are initially considered under the form $\alpha_{i}=\alpha_{0}+u \_i$ (model 7) and $\beta_{i}=\beta_{0}+$ $u_{-} i$ (model 8). The test of homogeneity of the enterprises therefore amounts to put forward as null hypothesis that all $u_{-} i=0$.

The reading of Fisher's test on the fixed effects model (Fisher's statistics below the estimation table) indicates us that at the threshold of $10 \%$, the fixed effects are significant according to the approaches as shown in the following table.

Table 7

Fisher's Tests

Fisher's test following the model VCRDT

$\mathrm{F}$ test that all $\mathrm{u} \mathrm{i}=0: \mathrm{F}(38,72)=1.49 \quad$ Prob $>\mathrm{F}=0.0734$

Fisher's test according to the model VCRDTexp

F test that all $\mathrm{u} \_\mathrm{i}: \mathrm{F}(38,72)=1.57 \quad$ Prob $>\mathrm{F}=0.0505$

There exist individual effects specific to enterprises that can explain their discretionary management of results.

Hausman's test in the table below enables to discriminate between fixed individual effects and random individual effects and indicates that fixed effects are significant following to the two models.

Table 8

Hausman's Statistical Test

Hausman's statistical test following VCRDT

$\operatorname{chi} 2(6)=(b-B) '\left[\left(V_{-} b-V \_B\right)^{\wedge}(-1)\right](b-B)=38.58$

Prob $>$ chi $2=0.0000$

Hausman's statistical test following VCRDTexp

$\operatorname{chi} 2(6)=(b-B) '\left[\left(V_{-} b-V \_B\right)^{\wedge}(-1)\right](b-B)=42.23$

Prob $>$ chi $2=0.0000$

Breuch and Pagan's test has been carried out to confirm the results of the previous tests. We notice as can be seen in the following table that the random effects are not significant at the threshold of $10 \%$. 
Table 9

Breuch's and Pagan's Test

\begin{tabular}{lll}
\hline According to VCRDT & \\
Test: $\operatorname{Var}(\mathrm{u})=0$ & chibar2 $(01)=0.00$ & Prob $>$ chibar $2=1.0000$ \\
\hline $\begin{array}{l}\text { According to VCRDT } \\
\text { Test: } \operatorname{Var}(\mathrm{u})=0\end{array}$ & $\operatorname{chibar} 2(01)=0.00$ & Prob $>$ chibar $2=1.0000$ \\
\hline
\end{tabular}

Given these results, we are led to consider that there exist fixed individual effects specific to each enterprise that explain discretionary management of accounting results. The constraints $\alpha_{\mathrm{i}}$ and $\beta_{\mathrm{i}}$ are considered as follows:

$$
\alpha_{i}=\alpha_{0}+u_{-} i \text { and } \beta_{i}=\beta_{0}+u_{-} i \text {. }
$$

The model selected is the model with fixed individual effects as follows:

$$
\begin{aligned}
& \text { VCRDT }_{i t}=\alpha_{i}+\alpha_{1} \text { CONCEN }{ }_{\text {it }}+\alpha_{2} \text { CONCEN }_{3}{ }_{\text {it }}+\alpha_{3} \text { ETRANG }_{\text {it }}+ \\
& \alpha_{4} \text { PubCAM }_{\text {it }}+\alpha_{5} \text { DETTE }_{\text {t-lit }}+\alpha_{6} \text { TAILLE }_{\text {it }}+\varepsilon_{\text {it }}
\end{aligned}
$$

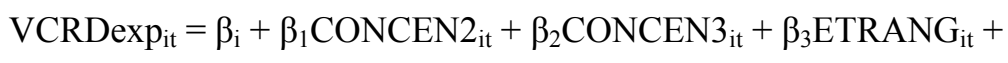

$$
\begin{aligned}
& \beta_{4} \text { PubCAM }_{\text {it }}+\beta_{5} \text { DETTE }_{\text {t-lit }}+\beta_{6} \text { TAILLE }_{\text {it }}+\varepsilon_{\text {it }}
\end{aligned}
$$

\section{Resultats of the Study}

In this section, we present the results of the regression above presented following the two models and whose formal model is as follows:

$\mathrm{VCRDT} \longrightarrow \mathrm{f}$ (nature of control, state property, foreign property)
$\mathrm{VCRDexp} \longrightarrow \mathrm{f}$ (nature of control, state property, foreign property)

Table 10

Regression Following the Two Models

\begin{tabular}{lllllll}
\hline \multirow{2}{*}{$\begin{array}{l}\text { Signs } \\
\text { anticipated variables }\end{array}$} & \multicolumn{3}{c}{ VCRDT } & \multicolumn{3}{c}{ Following VCRDexp } \\
\cline { 2 - 7 } Size - & 1.787596 & 4.13 & 0.000 & 1.704143 & 3.94 & 0.000 \\
Debts + & 3.658994 & 7.31 & 0.000 & 3.820527 & 7.64 & 0.000 \\
PubCAM + & 0.5918878 & 0.98 & 0.328 & 0.5762721 & 0.96 & 0.341 \\
Foriegn - & 0.1078285 & 0.36 & 0.718 & -0.0182413 & -0.06 & 0.951 \\
CONCEN3 + & 1.107392 & 0.66 & 0.514 & 1.113562 & 0.66 & 0.511 \\
CONCEN2 + & 21.56796 & 0.77 & 0.441 & 10.7909 & 0.39 & 0.699 \\
CONST -/+ & -25.49926 & -2.68 & 0.0009 & -21.35268 & -2.24 & 0.028 \\
F & 13.60 & & & 14.42 & & \\
Prob > F & 0.000 & & & 0.000 & & \\
R-sq: & & & & 0.5457 & & \\
$\quad$ Within & 0.5313 & & & 0.0243 & & \\
Between & 0.0291 & & & & 0.0505 & \\
Overall & 0.0474 & & & & & \\
\hline
\end{tabular}

The regression of the model with fixed individual effects shows that the model is significant at the threshold of $1 \%$. The model explains $53.13 \%$ of the variation of VCRDT variables and $54.57 \%$ of the variation of VCRDexp variables. This confirms that the model is well chosen, and the variables selected explain the discretionary management of accounting results. 
Control variables size and debt all display positive and significant coefficients following the two models, with a higher scope for the variable debt. Of greater size the enterprise is, the more managers manage the result upward. And the more the enterprise is indebted, the more managers are incited to manage the result upward in accordance with the hypothesis of the positivist theory of accountancy.

The weak and strong concentration of the capital constitutes conditions conducive to the management of accounting results. It does not deter the management of accounting results as pretended by the theory. In fact, the demands by shareholders of the control of the profitability of enterprises can push managers to opt for accounting choices which assess the results upward. And a shareholding which does not have or has less accounting and financial culture would not be able to appreciate the accounting choices of managers. This result is contrary to the prescriptions of the agency theory but matches Piot and Janin's studies (2004), Ramzi (2007). Contrary to Mard and Marsat (2012) for whom the concentration of capital till a certain threshold seems to dissuade the management of results and change the sign in case of exceeding this threshold, our study shows that whatever the degree of concentration (average or strong), it does not constitute a limit to the management of results. Our hypothesis " $\mathrm{H1}$ : The concentration of the shareholding dissuades the management of accounting results by managers" is thus invalidated in the Cameroonian context.

As far as public shareholding is concerned, a positive and non-significant coefficient is observed following the two models. We can say that the manipulation of results in order to minimize political cost is not significant. In public enterprises, the real control by shareholders seems to be absent. Managers are well motivated by their own interests because they don't bear the costs or profits of their choice. Our hypothesis "H2: State shareholding is negatively associated with the management of accounting results" is not validated.

Foreign shareholding displays a positive and non-significant coefficient following a long-term management of results and a negative coefficient following a short-term management of result. We can therefore say on the long-term, foreign shareholders lose interest in the control of managers, either because the expectation of earning they had placed is reached, or the manager is rooted. The hypothesis "foreign shareholding is negatively associated with the management of results" is partially validated.

\section{Managerial Implications}

The results of this research arouse managerial implications both at the practical and theoretical level. At the practical level, that can also be observed from the point of view of managers, shareholders, investors, and partners of the enterprise in general. For the managers of the enterprises, this study can constitute a way to clear themselves against shareholders. In fact, in accordance with the agency theory, managers bear the costs of customs clearance to prove their good management to shareholders. Thus, a shareholding concentration could then validate a good management by managers. For shareholders who are looking for medium of supervision of managers, this study could constitute a basis for the determination of the suitable shareholder structure in this sense. For investors, this study offers them the latitude to assess the financial situation and the reality of the enterprises in accounts. Therefore, the shareholder structure can constitute a guide for their decision-making. And finally, for partners who have legitimate claims against the enterprise, this study offers them the latitude to examine the reliability of financial information published and the real situation of enterprises. At the theoretical level, our study falls within the framework of the positivist theory of accounting drawing in itself its foundations of the agency theory. Then, our results seem to contrast with theoretical debates on the discretionary management of results and corporate governance. Our results confirm the necessity to carry out 
studies in the various contexts and in the unlisted companies.

\section{Conclusion}

In this research, our objective is to analyze within the Cameroonian context the link between the discretionary management of accounting results and the shareholder structure. The importance of this study is not to be demonstrated. Firstly, most studies enforcing the relation between the discretionary management of accounting results and shareholder structure have produced contrasted results. Moreover, this study enforces the degree of concentration of shareholding and the nature of shareholding as variable of shareholder structure. Finally, most studies have been carried out within the context of very active stammering financial market and, to our knowledge; no study has been carried out until now.

Our study is on a sample of industrial enterprises in Cameroon over the period 2013 to 2015. Shareholder structure is apprehended through shareholding concentration and the nature of shareholding particularly foreign shareholding and state shareholding has been mobilized as measure of corporate governance. The discretionary management of accounting results is apprehended through regulating accounting variables under two aspects that is: long term regulating accounting variables and short-term regulating accounting variables. This to take into consideration the fact that the management of accounting results can be affected by shareholder structure through long term posts as well as through short term ones. Jones's model (1991) is used to measure the discretionary part of those variables.

The results of this study enlighten us on the link between some governance mechanisms and the discretionary management of accounting results. Globally, we can say that the management of accounting results can be affected by the shareholder structure. Firstly, it appears that the degree of concentration of shareholders positively influences the discretionary management of accounting results. This leads us to say that the concentration of shareholders seems not to contain the opportunistic management of managers' results. Then, state's shareholding does not have significant effect on the management of accounting results. The real control of shareholders seems to be absent. Managers shall be well motivated by their own interests because they do not bear the costs of the profits of their choice. Finally, foreign shareholding is positively linked to the management of accounting results on the long term and is negative on the short term. This seems to result from the very demanding character in terms of profitability of foreign investors made in majority of institutional investors, because they would not have any reason to internationalize. They require to quickly having returns on their investment. On the long term, this requirement fades because they would have reached their requirements of gains placed in their investment. This could be explained by a short-term foreign investment horizon that would push them to be more active.

However, this study presents limits that could constitute new paths of research. We could take into consideration other characteristics of enterprises that could have an influence on the management of accounting results such as performance (Mard, 2004b). Then, we took into consideration in this study of the accounting form of management of results, overshadowing the real form of management. Finally, taking the only shareholder structure as mechanism of governance is very reductive. The analysis of conjugated effects of some mechanisms of governance as the role of the auditor, the board of directors, could give more rigors to the study. Orientating the study towards recent periods, widening to a wider sample, and carrying out a deeper analysis of modeling regulating discretionary accounting variables are all fields of research that seem promising to us. 


\section{References}

Affes, A., \& Romdhane, R. B. (2011). L'influence des administrateurs indépendants sur les pratiques de gestion réelle des résultats: Cas des entreprises tunisiennes. Comptabilités, économie et société (pp. Cd-rom). France: Montpellier.

Alexandre, H., \& Paquerot, M. (2002). Efficacité des structures de contrôle et enracinement des dirigeants. Finance-contrôle-Stratégie, 3(2), 5-29.

Amann, B. (1999). La théorie des droits de propriété. In G. Koenig (sous la coordination), De nouvelles théories pour gérer l'entreprise au XXI siècle (pp. 1-11). Economica.

Aubert, B. A., Patry M. et Rivard S. (2005). “A framework for information technology outsourcing risk management.” Database for Advances in Information Systems. 36 (4): 9-28.

Beffa, J. L. (2002). La gouvernance d'entreprise ou régime de gestion? Les entreprises de l'Europe continentale au fondement de la citoyenneté industrielle. Revue d'Economie Politique, 112(4), 463-469.

Belkaoui, A. R. (2013). Elément de théorie comptable. California, US: Create Space Independent Publishing Platform.

Bell, R. et Meiselman, H. L. (1995). The role of eating environments in determining food choice. In: Marshall, D. ed., Food Choice and the consumer, Blackie A \& P, Glascow.

Begne, J. M. (2012). Relation d'agence et comportements déviants: Le cas des entreprises publiques au Cameroun. Management International, 16(3), 165-173.

Berle, A. A., \& Means, G. C. (1932). The modern corporation and private property. New York: Macmillan.

Ben-Nasr, H., Boubakri, N., Cosset, J.-C. (2009). Ownership structure and earnings management quality: Evidence from newly privatized firms. Cahier de recherche.

Boussard, D. (1997). La modélisation comptable en question(s). Economica.

Boutant, J. (2009). Pratiques comptables des dirigeants en matière d'approche multicritères et de gestion des résultats lors des fusions-absorptions françaises. Centre de Recherche en Gestion.

Boutant, J. (2010). Les déterminants de la gestion des résultats lors des fusions: Étude des sociétés absorbantes initiatrices et cibles. Crises et Nouvelles Problématiques de la Valeur. France: Nice.

Brabet, J. (2002). La main invisible des investisseurs institutionnels. Revue Française de Gestion, 5(141), 203-224.

Breton, G., \& Schatt, A. (2003). Manipulation comptable: Les dirigeants et les autres parties prenantes. Workinppapers, Fargo.

Bughin, C., Finet, A., \& Monaco, C. (2011). L'influence des investisseurs institutionnels sur les orientations stratégiques des entreprises: Le cas du blue capital au sein du groupe Carrefour. La Revue des Sciences de Gestion, 2011/5(251), 177-188.

Caby, J. (2003). Convergence internationale des systèmes de gouvernance des entreprises: Faits et débats. Gregor. IAE Paris.

Caby, J., \& Hirigoyen, G. (2001). La création de valeur de l'entreprise. Economica.

Chaouki, G. (2008). La manipulation des résultats explique-t-elle la performance financière à moyen et long terme des émissions subséquentes d'actions? Mémoire présenté comme exigence partielle de la maîtrise en administration des affaires. Université du Québec à Montréal : 91 p.

Chaput, Y. (2005). Le monde idéal: Les principes de la gouvernance d'entreprise. Cahier de droit de l'entreprise, (5), 25-26.

Charlety, P. (2001). Le gouvernement d'entreprise: Évolution en France depuis le rapport Viénot de 1995. Revue d'Economie financière, (63), 25-34.

Charlety, P. (2004). Activisme des actionnaires: Le cas particulier des fonds de pension. Bulletin COB, (354), 17-29.

Charreaux, G. (1991). Structure de propriété, relation d'agence et performance financière. Revue Économique, (3), 521-552.

Charreaux, G. (1996). Vers une théorie du gouvernement de l'entreprise. CREGO/LATEC.

Charreaux, G. (1997). Le gouvernement d'entreprise.In Encyclopédie de gestion (pp. 1652-1662). Economica.

Charreaux, G. (1999). Théorie positive de l'agence: Lecture et relecture. In G. Koenig (Sous la coordination de), De nouvelles théories pour gérer l'entreprise du XXI ${ }^{\grave{e}}$ siècle. Economica, Gestion.

Charreaux, G., \& Desbrieres, P. (1998). Gouvernance d'entreprise: Valeur partenariale contrevaleur actionnariale. Finance-Contrôle-Stratégie, 1(2), 57-88.

Casta, J. F. (1997). Politique Comptable des Entreprises: Mesure des Résultats et du Patrimoine et Comportements Stratégiques Induits. Encyclopédie de Gestion. Economica.

Colasse, B. (1997). Qu'est-ce que la comptabilité. Encyclopédie de gestion. Economica.

Coriat, B., \& Weinstein, O. (1995). Les nouvelles théories de l'entreprise. Inédit, Economica.

Cormier, D., \& Magnan, M. (1995). La gestion stratégique des résultats: Le cas des firmes publiant des prévisions lors d'un premier appel public à l'épargne. Comptabilité-Contrôle-Audit, 1, 45-61. 
Cormier, D., Magnan, M., Morard, B. (1998). La gestion stratégique des résultats : Le modèle anglosaxon convient-il au contexte suisse ? Comptabilité-Contrôle-Audit, 4(1) : 25-48.

Daniel, E. M. (2001). Rôle et nature de l'actionnariat dans la vie des entreprises. Ceras-Revue Projet, 2001/2(266), 35-45.

Djelassi, M. (1996). Structure de propriété, relation d'agence et performance des firmes françaises cotées en bourse. Journal de la Société de Statistique de Paris, 137(3), 51-77.

Desbrières, P. (1997). Nouvelles formes de fonds propres et gouvernement de l'entreprise. In G. Charreaux (Sous la coordination de), Gouvernement des entreprises, Corporate governance, théories et faits. Economica, Paris.

Degeorge, F., Patel, J., \& Zeckhauser, R. (1999). Earnings management to exceed thresholds. The Journal of Business, 72(1), $1-33$.

Degos, J.-G., \& Souleymanou, K. (2016). Changements des paradigmes de la comptabilité financière pour une meilleure gouvernance des entreprises. Revue du financier, 38(221), 45.

Dempsey, S., Hunt, H., \& Schroeder, N. (1993). Earnings management and corporate ownership structure: An examination of extraordinary item reporting. Journal of Business, Finance and Accounting, 20(4), 479-500.

Djongoué, G. (2007). Fiabilité de l'information comptable et gouvernance d'entreprise: Une analyse de l'audit légal dans les entreprises camerounaises. Colloque international la gouvernance: Quelle pratique promouvoir pour le développement économique de l'Afrique. Université Catholique de Lille- France.

Djoutsa, W. L., Ndjanyou, L., \& Nga Nkouma, R. C. (2017). Investissements directs étrangers dans le capital des grandes entreprises au Cameroun: Quel effet sur leur performance? Marché et organisations, 2017/1(28), 81-104.

Doyle, J., Ge, W., \& McVay, S. (2007). Accruals quality and internal control over financial reporting. The Accounting Review. Forthcoming.

Dumontier, P. (1996). Spécificité de l'actif et structure financière de l'entreprise. Banque et Marchés, 24: 28-36.

Elage, A., \& Mard, Y. (2018). Code de gouvernance et gestion des résultats comptables: Le cas des sociétés françaises cotées. Comptabilité-Contrôle-Audit, 24(2), 113-147.

Fares, M. H., \& Saussier, S. (2002). Coûts de transactions et contrats incomplets. Revue Française d'Economie, 16(3), 193-230.

Fontagné, L. et Toubal, F. (2010). Investissements directs à l'étranger et performances des entreprises, Rapport du CAE, n 89.

Geoffron, P. (2000). La "Corporate Governance" et la restructuration du modèle japonais. La revue du CEPII, (84), 149-164.

Grossman, S. J., \& Hart, O. D. (1986). The cost and benefits of ownership: A theory of vertical and lateral integration. Journal of Political Economy, 94(4), 691-719.

Graham, R. J., Harvey, R. C., \& Rajgopal, S. (2004). The economic implications of corporate financial reporting. NBER Working Paper, No. 10550. National Bureau of Economic Research, Massachusset Avenue.

Grima, C. (2017). Impacts des normes IFRS sur la manipulation comptable des sociétés françaises cotées. Thèse de Doctorat en Sciences de Gestion. Conservatoire National des Arts et Métiers.

Gunny, K. (2005). What are the consequences of real earnings management? Cahier de recherche, Haas School of Business, University of California.

Healy, P. M., \& Wahlen, J. M. (1999). A review of the earnings management literature and its implications for standard setting. Accounting Horizons, 13(4), 365-383.

Hurlin, C. (2003). L'économétrie des données de panel, modèles linéaires simples. Séminaire méthodologique, École Doctorale Edocif.

Hyafil, A. (1997). Système financier et système de gouvernance. Encyclopédie des marchés financiers. Economica.

Jeanjean, T. (1999). La théorie positive de la comptabilité: Une revue des critiques. Working Papers hal-00601493, HAL.

Jeanjean, T. (2000). Contribution à l'analyse de la gestion du résultat des sociétés cotées. Communication au $22^{\grave{e}}$ congrès de l'Association Française de Comptabilité.

Jeanjean, T. (2001). Incitations et contraintes à gestion du résultat. Comptabilité-Contrôle-Audit, 7(1), 61-76.

Jeanjean, T. (2003). Gestion du résultat: Mesure et démesure ( 2 è version révisée). Centre de Recherche sur la Gestion.

Jensen, M. C., \& Meckling, W. H. (1976). Theory of the firm: Managerial behavior, agency cost, and ownership structure. Journal of Financial Economic, 3(4), 305-360.

Jones, J. (1991). Earnings management during import relief investigation. Journal of Accounting Research, 29(2), 193-228.

Kandou, K., \& Cormier, D. (2016). Gestion comptable et réelle des résultats et mode de financement des fusions-acquisitions. Cahier de recherche 05, Chaire d'information financière et organisationnelle, ESG UQAM.

Kang, S.-H., \& Sivaramakrishnan, K. (1995). Issues in testing earnings management and an instrumental variable approach. Journal of Accounting Research, 33(2), 353-367. 
Koenig, G. (1997). Théorie économique de l'entreprise. In Encyclopédie de gestion (pp. 1652-1662). Economica.

Labelle, R., \& Schatt, A. (2005). Structure de propriété et communication financière des entreprises françaises. Cahier du FARGO No. 1050701.

Lambert, C., Sponem, S. (2003). Gouvernance d'entreprise et gestion du résultat. Les contrôleurs de gestion « de l'autre côté du miroir ». Actes du 24ème congrès de l'Association Francophone de Comptabilité, Louvain, Belgique.

Lamrani, E. M. (2012). Éthique et gestion du résultat comptable. RIMHE: Revue Interdisciplinaire Management, Homme \& Entreprise, 2012/2(2), 17-32.

Mard, Y. (2004a). Les sociétés françaises cotées gèrent-elles leurs chiffres comptables afin d'éviter les pertes et les baisses de résultats? Comptabilité-Contrôle-Audit, 10(2), 73-98.

Mard, Y. (2004b). Vers une information comptable plus transparente: L'apport des recherches portant sur la gestion des résultats comptables. Communication au $22^{\grave{e}}$ congrès de l'Association Française de Comptabilité.

Mard, Y., \& Marsat, S. (2012). Gestion des résultats comptables et structure de l'actionnariat: Le cas français. Comptabilité-Contrôle-Audit, 3(18), 11-42.

Martinez, I. (2004). Le contenu informatif des chiffres comptables: Vers de nouvelles améliorations méthodologiques. Comptabilité-Contrôle-Audit, 10(2), 9-30.

Marmousez, S. (2009). Gestion du résultat. In Encyclopédie de Comptabilité, Contrôle de gestion et Audit (pp. 851-860). Economica.

Ndjanyou, L. (2008). Portée du système comptable OHADA sur la production et la diffusion de l'information financière des entreprises de petite taille. Revue Africaine de l'intégration, 2(2), 1-26.

OHADA. (2017). Acte uniforme relatif au droit comptable et à l'information financière, adopté le 26 janvier 2017 et paru au J. O. OHADA 15 février 2017.

Paulus, O., \& Fabrice, R. (2001). Gouvernement d'entreprise et Confiance: Une comparaison internationale. Revue d'Economie Financière, (63), 167-173.

Piot, C., \& Janin, R. (2004). Qualité de l'audit, gouvernance et gestion du résultat comptable en France. Communication au $22^{e ̀}$ congrès de l'association Française de comptabilité.

Piot, C., Janin, R. (2007). External auditors, audit committees earnings management in France. European Accounting Review, 16(2): 429-454.

Plihon, D., Ponsard, J. P., \& Zarlowski, P. (2001). Quel scénario pour le gouvernement de l'entreprise? Une hypothèse de double convergence. Revue d'Economie Financière, (63), 35-51.

Pochet, C. (1998). Inefficacité des mécanismes de contrôle managérial: Le rôle de l'information comptable dans le gouvernement de l'entreprise. Comptabilité-Contrôle-Audit, 4(2), 71-88.

Raimbourg, P. (1997). Asymétrie d'information, théorie de l'agence et gestion de l'entreprise. Encyclopédie de gestion. Economica.

Ramzi, B. (2007). L'influence des investisseurs institutionnels sur les stratégies comptables des dirigeants. Centre de Recherche en Gestion.

Raybaud-Turrillo, B., \& Teller, R. (1997). Comptabilité créative. Encyclopédie de gestion. Economica.

Roychowdhury, S. (2006). Earnings management through real activities manipulation. Journal of Accounting and Economics, 42(3), 335-370.

Royer, I., \& Zarlowski, P. (1999). Echantillons. In R. Thietart (sous la coordination), Méthode de recherche en management (pp. 188-223). France: Dunod.

Schipper, K. (1989). Commentary on earnings management. Accounting Horizons 15(4): 91-102.

Shleifer, A., Vishny, R.W. (1997). A survey of corporate governance. Journal of Finance, 52: 737-83.

Smith, E. (1976). The effect of the separation of ownership from control on accounting policy decisions. The Accounting Review, 51(4), 707-723.

Souleymanou, K., \& Degos, J.-G. (2018). Légitimité d'externalisation de la comptabilité: Faire produire le "bon" ou le "vrai" chiffre? Revue du Financier, 39-40(228-229), 34-49.

Stolowy, H. (2009). Comptabilité créative. In Encyclopédie de Comptabilité, Contrôle de gestion et audit (pp. 186-207). (2 $2^{\mathrm{ème}}$ édition). Economica.

Stolowy, H., \& Breton, G. (2003). La gestion des données comptables: Une revue de littérature. Comptabilité-Contrôle-Audit, $9(1), 125-152$. 
Teoh, S. H., Welch, I., \& Wong, T. J. (1998). Earnings management and the underperformance of seasoned equity offerings. Journal of Financial Economics, 50(1), 63-99.

Wanda, R. (2001). Structure financière et performance des entreprises dans un contexte sans marché financier: Le cas du Cameroun. Revue du Financier.

Watts, R., Zimmerman, J. (1990). Positive accounting theory: a ten-year perspective. The Accounting Review, 65(1):131-56.

Watts, R., Zimmerman, J. (1986). Positive accounting theory. Englowood Cliffs, N. J., Prentice Hall. 


\section{Appendix A}

Résultat régression sous STATA

\section{VCRDT}

- xtreg VCRTd taille dette pubCAM ETRANg CONCEn2 CONCEN3, fe

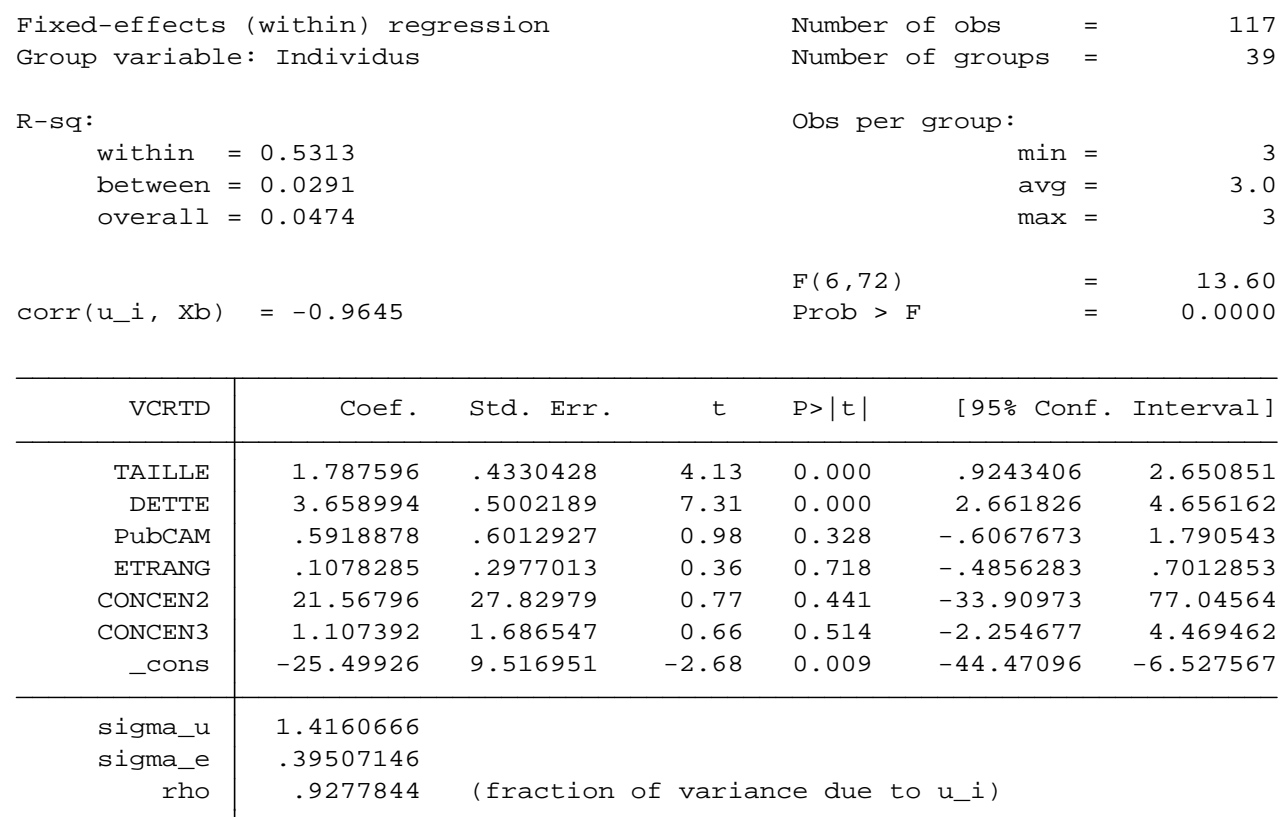

F test that all u_i=@: $F(38,72)=1.49$

- xtreg VCRTD TAILLE DETTE PubCAM ETRANG CONCEN2 CONCEN3, re

Random-effects GLS regression Group variable: Individus

R-sq :

within $=0.4255$

between $=0.2603$

overall $=0.2963$

$\operatorname{corr}\left(u_{-} i, X\right)=0$ (assumed $)$

\section{Number of obs=} Number of groups $=$

Obs per group:

$\begin{array}{rlr}\min & = & 3 \\ \operatorname{avg}= & 3.0 \\ \max = & 3\end{array}$

Wald $\operatorname{chi2}(6)=46.32$

Prob $>$ chi2 $=0.0000$

\begin{tabular}{|c|c|c|c|c|c|c|c|}
\hline VCRTD & Coef. & Std. Err. & $z$ & $P>|z|$ & & [95\% Conf. & Interval] \\
\hline TAILLE & .0782457 & .0572582 & 1.37 & 0.172 & & - .0339782 & .1904697 \\
\hline DETTE & 2.272997 & .3425968 & 6.63 & 0.000 & & 1.60152 & 2.944475 \\
\hline PubCAM & .006403 & .1827849 & 0.04 & 0.972 & & -.3518488 & .3646548 \\
\hline ETRANG & - . .0697251 & .1005425 & -0.69 & 0.488 & & -.2667847 & .1273345 \\
\hline CONCEN2 & .7654572 & 22.08284 & 0.03 & 0.972 & & -42.51611 & 44.04703 \\
\hline CONCEN3 & .1358918 & .1949369 & 0.70 & 0.486 & & - . 2461776 & .5179612 \\
\hline _cons & -1.232469 & 6.699343 & -0.18 & 0.854 & & -14.36294 & 11.898 \\
\hline sigma_u & $\odot$ & & & & & & \\
\hline sigma_e & .39507146 & & & & & & \\
\hline rho & 0 & (fraction & varia & ce due & to & u_i) & \\
\hline
\end{tabular}


hausman fe re

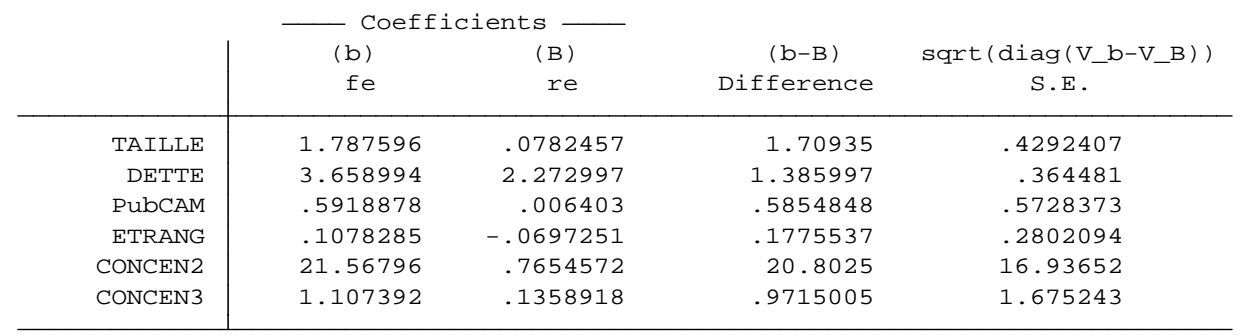

$\mathrm{b}=$ consistent under $\mathrm{Ho}$ and $\mathrm{Ha}$; obtained from $\mathrm{xtreg}$ $B=$ inconsistent under $\mathrm{Ha}$, efficient under Ho; obtained from xtreg

Test: Ho: difference in coefficients not systematic

$$
\begin{aligned}
& \operatorname{chi2}(6)=(b-B)^{\prime}\left[\left(V \_b-V \_B\right)^{\wedge}(-1)\right](b-B) \\
& \begin{array}{rrr} 
& = & 38.58 \\
\text { Prob }>\text { chi2 }= & & \odot . \odot \odot \odot \odot
\end{array}
\end{aligned}
$$

- xttesto

Breusch and Pagan Lagrangian multiplier test for random effects

VCRTD[Individus, $\mathrm{t}]=\mathrm{Xb}+\mathrm{u}$ [Individus $]+\mathrm{e}$ [Individus, $\mathrm{t}]$

Estimated results:

\begin{tabular}{r|rr} 
& Var & sd $=\operatorname{sqrt}($ Var $)$ \\
\hline VCRTD & .2458417 & .4958243 \\
$\mathrm{e}$ & .1560815 & .3950715 \\
$\mathrm{u}$ & $\odot$ & $\odot$
\end{tabular}

Test: $\quad \operatorname{var}(\mathrm{u})=\odot$

$$
\begin{aligned}
\frac{\text { chibar } 2(\odot 1)}{=} & \odot . \odot \odot \\
\text { Prob }>\text { chibar } 2 & =1 . \odot \odot \odot \odot
\end{aligned}
$$

2. VCRDTexp

. xtreg VCRDexp TAILLE DETTE PubCAM ETRANG CONCEN2 CONCEN3, fe

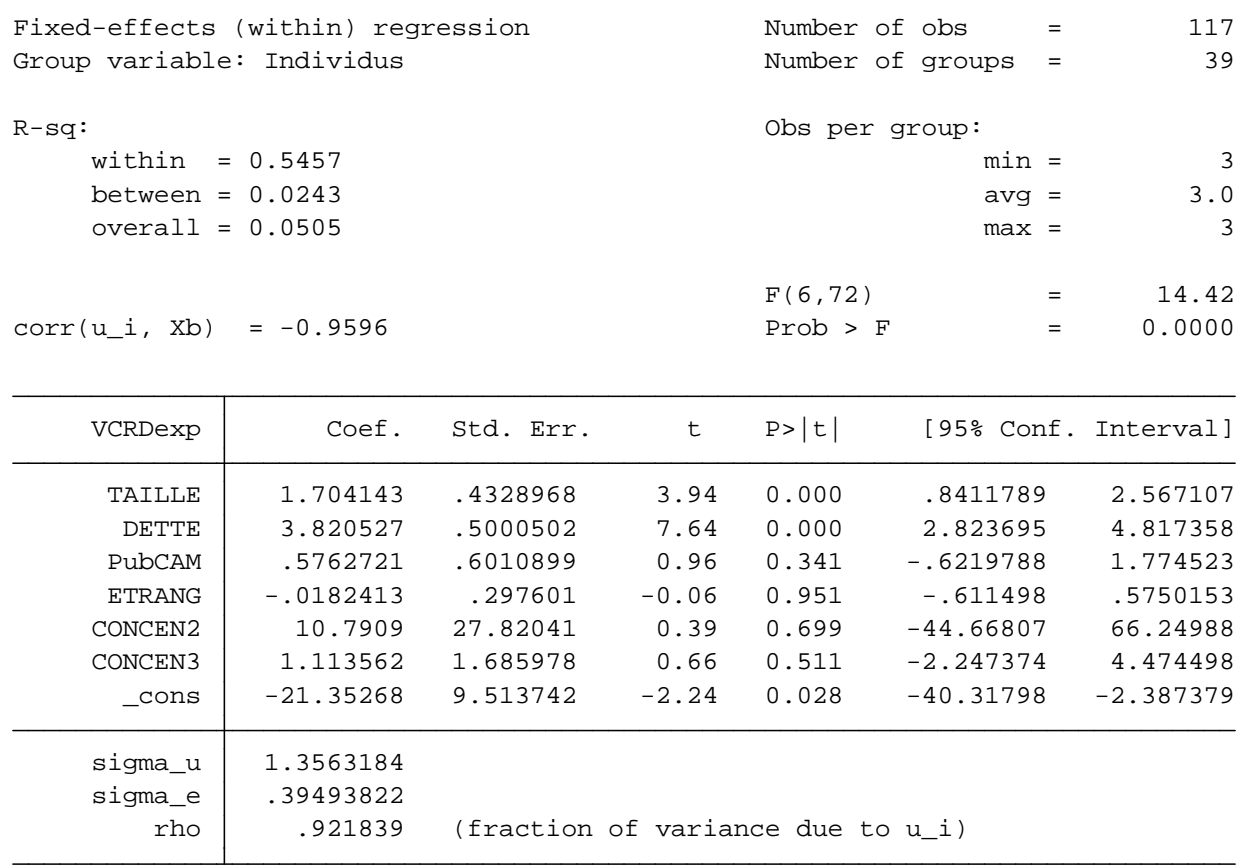

$F$ test that all $u_{-} i=0: F(38,72)=1.57$

Prob $>F=0.0505$ 
- xtreg VCRDexp TAILLE DETTE PUbCAM ETRANG CONCEN2 CONCEN3, re

Random-effects GLS regression Group variable: Individus

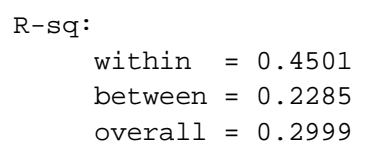

Number of obs= $=$ Number of groups =

117

39

Obs per group:

$\begin{array}{rr}\min = & 3 \\ \operatorname{avg}= & 3.0 \\ \max = & 3\end{array}$

Wald $\operatorname{chi2}(6)=47.11$

Prob $>$ chi2 $=0.0000$

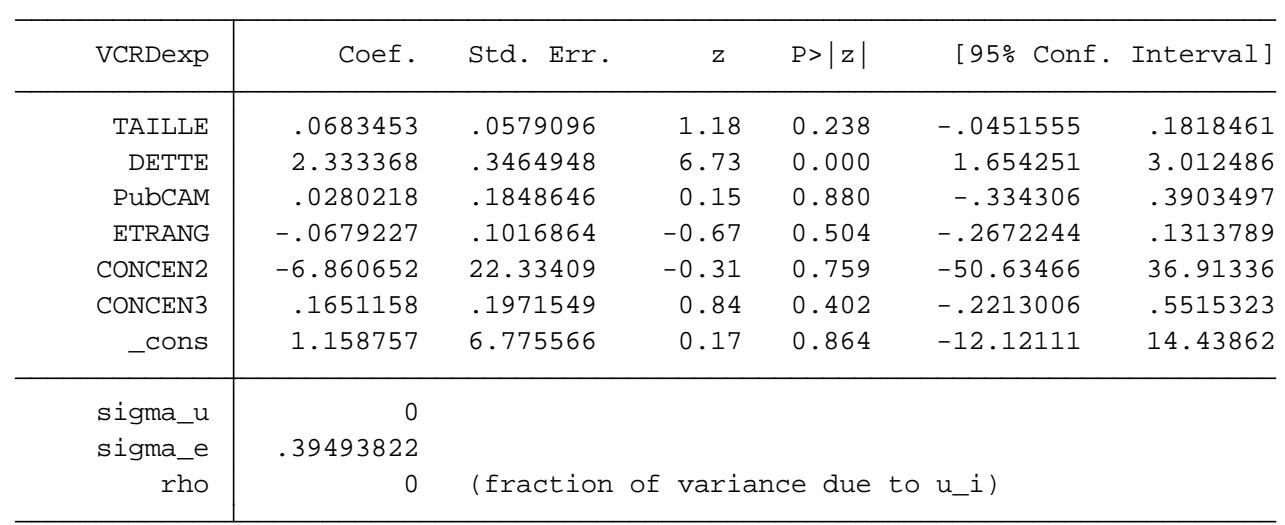

hausman fe re

\begin{tabular}{|c|c|c|c|c|}
\hline & \multicolumn{2}{|c|}{ - Coefficients } & \multirow{3}{*}{$\begin{array}{c}(b-B) \\
\text { Difference }\end{array}$} & \multirow{3}{*}{$\begin{array}{c}\operatorname{sqrt}\left(\operatorname{diag}\left(V \_b-V \_B\right)\right) \\
\text { S.E. }\end{array}$} \\
\hline & (b) & (B) & & \\
\hline & & re & & \\
\hline TAILLE & $1.7 \odot 4143$ & .0683453 & 1.635798 & $.4290 \odot 59$ \\
\hline DETTE & 3.820527 & 2.333368 & 1.487158 & .3605435 \\
\hline PubCAM & .5762721 &.$\odot 28 \odot 218$ & .5482502 & .5719565 \\
\hline ETRANG & - . .0182413 & - . .0679227 & .0496814 & .2796895 \\
\hline CONCEN2 & 10.7909 & -6.860652 & 17.65155 & 16.58806 \\
\hline CONCEN3 & 1.113562 & .1651158 & .9484461 & 1.674411 \\
\hline
\end{tabular}

$\mathrm{b}=$ consistent under $\mathrm{Ho}$ and $\mathrm{Ha}$; obtained from $x$ treg $\mathrm{B}=$ inconsistent under $\mathrm{Ha}$, efficient under $\mathrm{Ho}$; obtained from $\mathrm{xtreg}$

Test: Ho: difference in coefficients not systematic

$$
\begin{aligned}
& \operatorname{chi2}(6)=(b-B)^{\prime}\left[\left(V \_b-V \_B\right)^{\wedge}(-1)\right](b-B)
\end{aligned}
$$

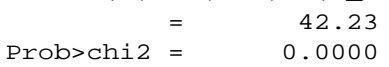

xttest $\odot$

Breusch and Pagan Lagrangian multiplier test for random effects

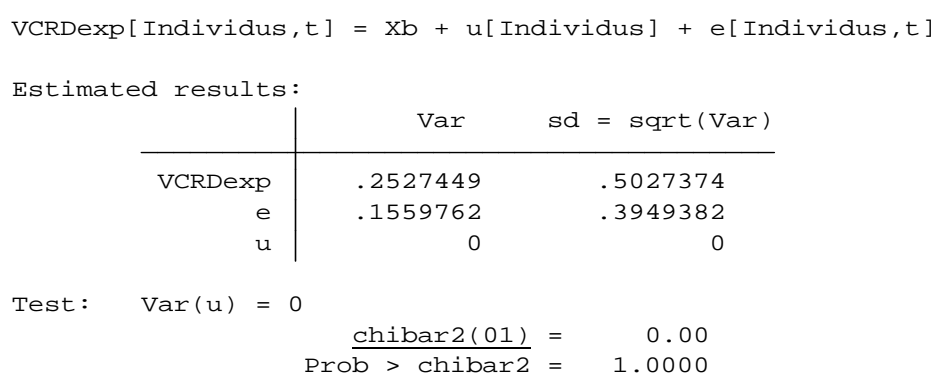


(1) Within: The R-squared from the mean-deviated regression, i.e., the ordinary r-squared from running OLS on the transformed data.

(2) Between: First, this computes the fitted values using the fixed-effects parameter vector and the within-individual means of the independent variables. Then calculates the r-squared as the squared correlation between those predicted values and the within-individual means of the original y variable.

(3) Overall: First, this computes the fitted values using the fixed-effects parameter vector and the original, untransformed independent variables. Then calculates the r-squared as the squared correlation between those predicted values and the original, untransformed y variable. 